\title{
The analysis of dimensional stability of 1x1 RIB CO and CO/LY knitwear
}

\section{REZUMAT - ABSTRACT}

\section{Analiza stabilității dimensionale a tricoturilor patent 1x1 CO și CO/LY}

Această lucrare analizează impactul compoziției fibroase, a densității liniare și finisajului firelor asupra stabilității dimensionale a tricotului patent $1 \times 1$ realizat pe mașina de tricotat circulară. Stabilitatea dimensională a fost analizată prin metoda FAST 4. Diferite probe au fost comparate prin intermediul mai multor indicatori. Rezultatele arată că cea mai stabilă variantă tricotată, vopsită este din: 96\% CO / 4\% Lycra și fire cu densitate liniară 19,14 tex. Valorile factorului de etanșeitate în stare uscată de relaxare s-au situat la 17,90, în cea umedă la 18,45, în total 18,73 și 18,59 în condiții de climatizare standard. Tricoturile cu cele mai ridicate valori ale instabilității dimensionale sunt tricoturile crude din $100 \%$ CO și fire cu densitate liniară de 13,39 tex. Valoarea factorului de etanșeitate în stare uscată de relaxarea a fost de 12,16, în cea umedă la 12,36, în total 13,26 și 13,35 în condiții de climatizare standard.

Cuvinte-cheie: constante dimensionale, factor de etanșeitate, metoda FAST 4, lungimea firului

\section{The analysis of dimensional stability of 1X1 RIB CO and CO/LY knitwear}

This paper analyzes the impact of knitwear's fiber composition, linear density and finishing of yarn used in the dimensional stability of the $1 \times 1$ RIB knitwear made on the same circular knitting machine. Dimensional stability of these samples was analysed by FAST 4 method. Different samples were compared across multiple indicators. The results show that the most stable dyed knitted fabric are made of cotton $96 \%$ and $4 \%$ of Lycra and of yarn with linear density 19.14 tex. Tightness factor's values in the dry relaxation stood at 17.90, in the wet 18.45, in total 18.73 and 18.59 in air conditioned terms. Knitwear with the highest values of dimensional instability are raw knitted fabric made of $100 \%$ CO, and yarn with linear density of 13.39 tex. Tightness factor's values in the dry relaxation stood at 12.16, in the wet 12.36, in total 13.26 and 13.35 in air conditioned terms.

Keywords: dimensional constants, the tightness factor, FAST 4 method, yarn length

\section{INTRODUCTION}

Knitted products are clasified as unstable products in dimensional stability point of view. This is due to the fact that, a variety of different loads affect knitwear's production process and also nature of knitwear structure itself. Therefore in the yarn, which has formed a loop, a certain amount of potential energy is accumulated and causes a certain pressure yarn against yarn in places where these yarns intersect in knitwear. On these places, between the yarns frictional forces appear which prevent their displacement. Yarn tends to free of deformations that have occurred in the shaping of the loop which causes a shrinkage. Knitwear's shrinkage stops when these deformation and friction forces are in balance [1].

Due the fact that several external factors simultaneously influence on the shrinking of knitwear, their individual impact is difficult to measure. Therefore, analisys conducts impact of raw materials selection, knitting machine, knitting conditions and the impact of knitwear's finishing [2].

Characteristics of fiber significantly affect knitwear's shrinkage. For example, natural cellulose fibers have a small area of elastic deformation while synthetic fibers are more elastic and much faster occupy steady state [2].
The impact of treatment is also significant. Wet finishing method leads to the relaxation of knitwear. The water molecules during penetration into intermicellar spaces cellulose fibers, lead to swelling of fibers and as result yarn's diameter in the loop increases by 20 to $30 \%$ [3]. Wet processing usually is accompanied by increasing temperature of processing agents [4]. All this leads to shrinkage knitwear.

When designing clothing products nig issue is the prediction of dimensional stability of knitwear. This problem is expressed during the exploitation of knitted products as well as during their washing, because very often there are significant dimensional changes in clothing products that reduce their quality.

\section{MATERIAL AND METHODS}

Experimental part of this paper analyses the dimensional stability of the $1 \times 1$ RIB knitted fabric made of $100 \%$ CO yarns and CO yarns in combination with LY ( $96 \%$ CO/4 \% LY). Linear density of LY which was used is 44 dtex. CO yarn was used in two linear densities: 19.14 tex and 13.39 tex. Samples in the raw state and stained samples were examined (table 1). Knitwear are made on a circular knitting machine type Fv 2.0 of company Mayer \& Cie. Characteristics of the machine are as follows: cylinder diameter 19" (inch), the gauge is E18 and with 40 feeders, the 


\begin{tabular}{|c|c|c|c|c|c|c|c|c|}
\hline Samples & $\mathrm{A}_{1}$ & $\mathrm{~A}_{2}$ & $\mathrm{~A}_{3}$ & $\mathrm{~A}_{4}$ & $\mathrm{~B}_{1}$ & $\mathrm{~B}_{2}$ & $\mathrm{~B}_{3}$ & $\mathrm{~B}_{4}$ \\
\hline Structure & $1 \times 1 \mathrm{RIB}$ & $1 \times 1 \mathrm{RIB}$ & $1 \times 1 \mathrm{RIB}$ & $1 \times 1 \mathrm{RIB}$ & $1 \times 1 \mathrm{RIB}$ & $1 \times 1 \mathrm{RIB}$ & $1 \times 1 \mathrm{RIB}$ & $1 \times 1 \mathrm{RIB}$ \\
\hline $\begin{array}{c}\text { Fiber } \\
\text { composition }\end{array}$ & $100 \% \mathrm{CO}$ & $100 \% \mathrm{CO}$ & $\begin{array}{c}96 \% \mathrm{CO} / \\
4 \% \mathrm{LY}\end{array}$ & $\begin{array}{c}96 \% \mathrm{CO} / \\
4 \% \mathrm{LY}\end{array}$ & $100 \% \mathrm{CO}$ & $100 \% \mathrm{CO}$ & $\begin{array}{c}96 \% \mathrm{CO} / \\
4 \% \mathrm{LY}\end{array}$ & $\begin{array}{c}96 \% \mathrm{CO} / \\
4 \% \mathrm{LY}\end{array}$ \\
\hline $\begin{array}{c}\text { Linear density } \\
\text { tex/dtex) }\end{array}$ & 19,14 & 13,39 & $19,14 / 4,4$ & $13,39 / 4,4$ & 19,14 & 13,39 & $19,14 / 4,4$ & $13,39 / 4,4$ \\
\hline Twists (m-1) & 565 & 693 & $565 /-$ & $693 /-$ & 565 & 693 & $565 /-$ & $693 /-$ \\
\hline Finishing & raw & raw & raw & raw & dyed & dyed & dyed & dyed \\
\hline
\end{tabular}

knitting speed is $1.7 \mathrm{~m} / \mathrm{s}$. All of the samples are knitted under the same conditions and same machine.

Dimensional stability of samples was analysed by FAST 4 method. Measurment was performed on 20 samples of the same type and in measurment result in the following, the arithmetic mean values of these 20 samples is represented.

Determination of the dimensional stability by the FAST 4 method

Sample's dimensions were $300 \times 300 \mathrm{~mm}$ and they were taken with $5 \mathrm{~cm}$ minimum distance from the edges of a knitted fabric.

FAST 4 method consists of several stages [5]. First, the conditioned samples of knitted fabric has to be exposed to heat at a temperature of $105^{\circ} \mathrm{C}$ in a dryer for 60 min period, after which dimension of samples have to be taken in the longitudinal and transverse direction for a period of 30 seconds (length L1). That is followed by immersion of a dry sample for 30 minutes in water at a temperature of $25^{\circ} \mathrm{C}$ to $30^{\circ} \mathrm{C}$ with the addition of $0.1 \%$ detergent. After that, sample has to be placed on smooth surface with gentle pressing in order to remove excess water, after which the sample should be measured again (length L2). The sample is then returned to the dryer to be exposed to heat at a temperature of $105^{\circ} \mathrm{C}$ for $60 \mathrm{~min}$. The dried sample is measured over a period of 30 seconds to obtain the length L3. At the end the sample is left for relaxation, and after conditioning in a room with standard atmospheric conditions according to ISO 139 the sample is measured (length L4).

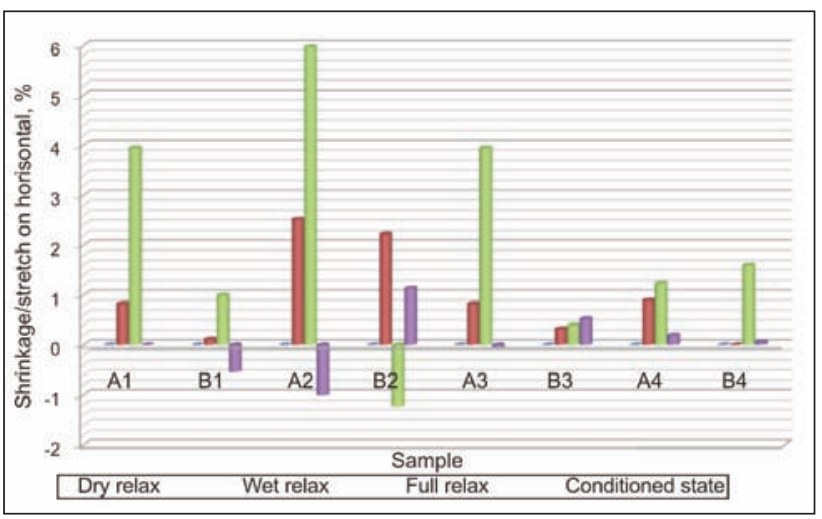

Fig. 1. Results of shrinkage/stretch of knittung material on horisontal
According to the method FAST 4, relaxing shrinkage is defined as percentage change of knitwear sample's dimension after the heat and wet processing. It can be described as the ratio of the difference between the dry sample length after heat treatment (length L1) and the dimension of the dried sample after relaxation at a wet state (length L3) and dimension of dry sample after the heat treatment (length L1). Relaxational shrinkage of knitwear's sample can be represented by following expression 1 [5]:

$$
R S=\frac{L_{1}-L_{3}}{L_{1}} \cdot 100[\%]
$$

FAST 4 method defines relaxing stretching in a wet condition as the percentage change of dimension of the knitwear's sample upon wet treatment and is calculated according to following expression 2 [5]:

$$
H E=\frac{L_{2}-L_{3}}{L_{2}} \cdot 100[\%]
$$

\section{RESULTS AND DISCUSSION}

Figure 1 shows the values of shrinkage/stretch on horisontal axis for all samples shown in table 1, i.e. for all raw samples: A1, A2, A3 and A4 and stained samples B1, B2, B3 and B4. Figure 2 shows the same values but measured on vertical axis of knitted samples.

In figure 1 and 2, we can see that the raw samples of knitwear made from finer yarns have less shrinkage of the knitted fabric which are made of coarser and stronger yarn. Samples with Lycra show that Lycra contributes to greater stabilization of knitwear. Also it

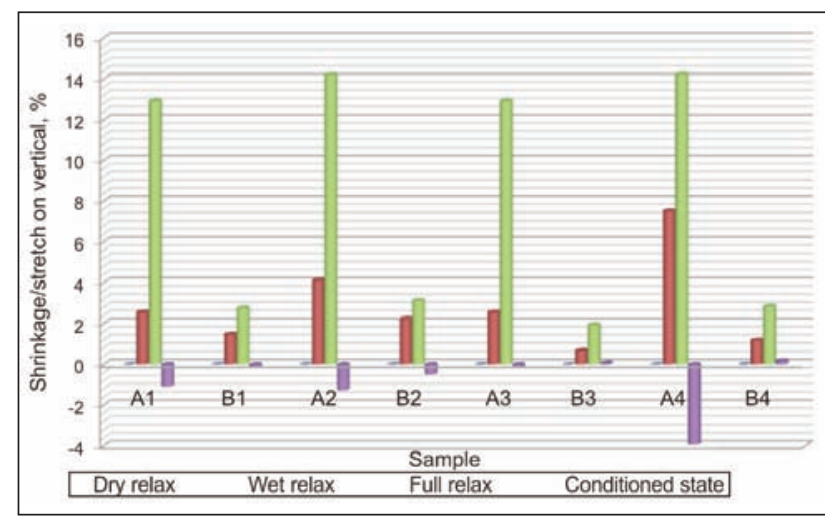

Fig. 2. Results of shrinkage/stretch of knittung material on vertical 
can be seen that samples of colored knitwear have a significantly greater dimensional stability than the samples of raw knitwear. This is due to stabilization of knitwear in the technological stage of coloring. This stabilization is further increased when $4 \%$ Lycra is added into cotton knitwear. Figures also show that samples of the raw knitted fabric is woven from finer yarns have less vertical and horizontal shrinkage comparing with knitwear made from the coarser and stronger yarn.

\section{Dimensional constants K-values}

In order to monitor the stability of the knitted structure through different state of relaxation, dimensional constants can be used. Usually, following Munden's geometrical correlation are used [1] for calculating the dimensional constants of knitwear 4 relaxation conditions:

$$
K_{c}=\frac{D_{h}}{l} ; \quad K_{w}=\frac{D_{v}}{l} ; \quad K_{r}=\frac{K_{c}}{K_{w}} ; \quad K_{s}=S \cdot l^{2}
$$

$I$ is the mean value of the yarn's length in a loop, $K_{c}$, $K_{w}, K_{r}$ and $K_{s}$ - dimensional constants.

$K$ values are important for prediction of the structural behavior, to create a material with better stability, for determining the minimum/lower energy level of loops after treatment. $K$ constants can interconnect values $D_{h}, D_{v}$ and yarn's length in a loop. $K_{w}$ and $K_{c}$ are constants of $D_{v}$ and $D_{h} . K_{r}$ constant represents the ratio of the constants $K_{c} / K_{w}$. This is a direct measure of a loop's shape and it is called the shape factor of the loop. $K_{s}$ is a constant overall density of loops. It is the product constants $K_{c}$ and $K_{w}$ [1]. Table 2 shows the value of dimensional constants for the test samples.
The results shown in table 2 , indicate that the values of the dimensional constants increase with increasing relaxation, except for the conditioned samples where the values decrease. Knitwear made of $96 \%$ CO and $4 \%$ LY give different values of knitwear made of $100 \% \mathrm{CO}$, because they have a greater angle of recovery and this is due to their more elastic properties.

The difference can be seen between raw and dyed knitwear. Constants $K_{w}, K_{c}$ and $K_{s}$ are significantly lower with raw knitwear. Values of the constants rise with the knitted fabric which is made of thicker cotton yarns, comparing with ones made by thinner cotton yarn. Also with the change of the relaxation condition, it can be seen that $K_{r}$ constant or a loop's shape factor is significantly reduced as a result of achieving a stable condition.

According to the results shown in table 2, knitted fabrics which are made of a mixture of $100 \% \mathrm{CO}$ and $4 \%$ LY faster reach stable condition. It can also be noted that colored knitwear attain stable condition quicker than raw samples.

\section{Tightness factor variations}

Tightness factor represents a measure of fabric density and it can be calculated by the following equation 4 [1]:

$$
\text { tightness factor }(\mathrm{TF})=\frac{\sqrt{T t}}{l} \quad\left[\operatorname{tex}^{1 / 2} \mathrm{~cm}^{-1}\right]
$$

Or, it can be represented as structural tightness factor [1]:

$$
(\mathrm{STF})=T F \cdot K_{S}\left[\mathrm{tex}^{1 / 2} \mathrm{~cm}^{-1}\right]
$$

\begin{tabular}{|c|c|c|c|c|c|c|c|c|c|}
\hline & & $A_{1}$ & $A_{2}$ & $A_{3}$ & $A_{4}$ & $\mathrm{~B}_{1}$ & $\mathrm{~B}_{2}$ & $\mathrm{~B}_{3}$ & $\mathrm{~B}_{4}$ \\
\hline$I$ & $\mathrm{~cm}$ & $0.280 \pm 0.0111$ & $0.289 \pm 0.0121$ & $0.0272 \pm 0.0122$ & $0.269 \pm 0.0079$ & $0.270 \pm 0.0048$ & $0.274 \pm 0.0063$ & $0.264 \pm 0.0046$ & $0.0262 \pm 0.0038$ \\
\hline \multirow{4}{*}{ Kw } & $\mathrm{D}$ & $3.09 \pm 0.0344$ & $3.61 \pm 0.0437$ & $4.72 \pm 0.0572$ & $4.84 \pm 0.0384$ & $3.28 \pm 0.0156$ & $3.68 \pm 0.0233$ & $5.07 \pm 0.0231$ & $5.49 \pm 0.0209$ \\
\hline & W & $3.22 \pm 0.0357$ & $3.67 \pm 0.0444$ & $4.84 \pm 0.0585$ & $5.07 \pm 0.0403$ & $3.39 \pm 0.0162$ & $3.87 \pm 0.0245$ & $5.19 \pm 0.0237$ & $5.54 \pm 0.0211$ \\
\hline & $F$ & $3.30 \pm 0.0367$ & $4.11 \pm 0.0497$ & $5.15 \pm 0.0623$ & $5.37 \pm 0.0427$ & $3.43 \pm 0.0164$ & $4.05 \pm 0.0257$ & $5.49 \pm 0.0250$ & $5.67 \pm 0.0216$ \\
\hline & $\mathrm{C}$ & $3.22 \pm 0.0358$ & $4.08 \pm 0.0495$ & $5.03 \pm 0.0609$ & $5.30 \pm 0.0422$ & $3.40 \pm 0.0162$ & $4.01 \pm 0.0245$ & $5.46 \pm 0.0249$ & $5.68 \pm 0.0216$ \\
\hline \multirow{4}{*}{ Kc } & $D$ & $6.10 \pm 0.0678$ & $6.7 \pm 0.0812$ & $6.48 \pm 0.0785$ & $6.86 \pm 0.0546$ & $6.55 \pm 0.0312$ & $7.42 \pm 0.0471$ & $7.07 \pm 0.0322$ & $7.87 \pm 0.0300$ \\
\hline & $W$ & $6.14 \pm 0.0682$ & $6.9 \pm 0.0835$ & $6.54 \pm 0.0791$ & $6.95 \pm 0.0552$ & $6.58 \pm 0.0314$ & $7.56 \pm 0.0479$ & $7.12 \pm 0.0325$ & $7.89 \pm 0.0301$ \\
\hline & $F$ & $6.34 \pm 0.0705$ & $7.12 \pm 0.0863$ & $7.03 \pm 0.0850$ & $6.98 \pm 0.0555$ & $6.69 \pm 0.0$ & $7.35 \pm 0.0466$ & $7.20 \pm 0.0328$ & $8.02 \pm 0.0306$ \\
\hline & $C$ & $6.31 \pm 0.0701$ & $7.01 \pm 0.0849$ & $7.01 \pm 0.0846$ & $6.96 \pm 0.0$ & $6.66 \pm 0.0318$ & $7.32 \pm 0.0464$ & $7.13 \pm 0.0325$ & $8.01 \pm 0.0305$ \\
\hline \multirow{4}{*}{$\mathrm{Kr}$} & $D$ & $1.97 \pm 0.0219$ & $1.86 \pm 0.0225$ & $1.37 \pm 0.0166$ & $1.42 \pm 0.0113$ & $2.00 \pm 0.0095$ & $2.02 \pm 0.0128$ & $1.39 \pm 0.0064$ & $1.43 \pm 0.0055$ \\
\hline & $W$ & $1.91 \pm 0.0212$ & $1.88 \pm 0.0228$ & $1.35 \pm 0.0164$ & $1.37 \pm 0.0109$ & $1.94 \pm 0.0093$ & $1.95 \pm 0.0124$ & $1.37 \pm 0.0063$ & $1.43 \pm 0.0054$ \\
\hline & $\mathrm{F}$ & $1.92 \pm 0.0213$ & $1.73 \pm 0.0210$ & $1.36 \pm 0.0165$ & $1.30 \pm 0.0103$ & $1.95 \pm 0.0093$ & $1.80 \pm 0.0115$ & $1.31 \pm 0.0060$ & $1.42 \pm 0.0054$ \\
\hline & $C$ & $1.96 \pm 0.0218$ & $1.72 \pm 0.0208$ & $1.39 \pm 0.0168$ & $1.31 \pm 0.0104$ & $1.96 \pm 0.0093$ & $1.82 \pm 0.0116$ & $1.31 \pm 0.060$ & $1.41 \pm 0.0054$ \\
\hline \multirow{4}{*}{ Ks } & $D$ & $18.89 \pm 0.2099$ & $24.18 \pm 0.2929$ & $30.62 \pm 0.3706$ & $33.2 \pm 0.2639$ & $21.47 \pm 0.1024$ & $27.28 \pm 0.1731$ & $35.84 \pm 0.1632$ & $43.24 \pm 0.1647$ \\
\hline & $W$ & $19.75 \pm 0.2195$ & $25.3 \pm 0.3064$ & $31.62 \pm 0.3826$ & $35.2 \pm 0.2798$ & $22.32 \pm 0.1065$ & $29.25 \pm 0.1854$ & $36.92 \pm 0.1684$ & $43.69 \pm 0.1665$ \\
\hline & $\mathrm{F}$ & $20.94 \pm 0.2326$ & $29.26 \pm 0.3543$ & $36.18 \pm 0.4377$ & $37.47 \pm 0.2979$ & $22.97 \pm 0.1096$ & $29.78 \pm 0.1888$ & $39.49 \pm 0.1801$ & $45.48 \pm 0.1733$ \\
\hline & C & $20.35 \pm 0.2261$ & $28.62 \pm 0.3466$ & $35.20 \pm 0.4260$ & $36.94 \pm 0.2937$ & $22.64 \pm 0.1080$ & $29.39 \pm 0.1863$ & $38.93 \pm 0.1775$ & $45.49 \pm 0.1733$ \\
\hline
\end{tabular}

where: TF is tightness factor, tex ${ }^{1 / 2} \mathrm{~cm}^{-1} ; \mathrm{Tt}$ - linear density, tex; I- yarn's length in a loop, $\mathrm{cm}$.

Legend: D - dry relaxation, $\mathrm{W}$ - wet relaxation, $\mathrm{F}$ - full relaxation, $\mathrm{C}$ - conditioned sample, $I$ - the mean value of the yarn's length in a loop $(\mathrm{cm})$. 


\begin{tabular}{|c|c|c|c|c|c|c|c|c|}
\hline & \multicolumn{4}{|c|}{ TF } & \multicolumn{4}{c|}{ STF } \\
\cline { 2 - 9 } & $\mathrm{D}$ & $\mathrm{W}$ & $\mathrm{F}$ & $\mathrm{C}$ & $\mathrm{D}$ & $\mathrm{W}$ & $\mathrm{F}$ & $\mathrm{C}$ \\
\hline $\mathrm{A}_{1}$ & 14.93 & 15.14 & 16.32 & 16.20 & 281.99 & 299.05 & 341.77 & 329.72 \\
\hline $\mathrm{A}_{2}$ & 12.16 & 12.36 & 13.26 & 13.35 & 293.98 & 312.76 & 387.87 & 382.20 \\
\hline $\mathrm{A}_{3}$ & 16.96 & 17.20 & 18.73 & 18.59 & 519.43 & 544.07 & 677.67 & 654.40 \\
\hline $\mathrm{A}_{4}$ & 15.01 & 15.51 & 16.04 & 16.16 & 498.38 & 545.83 & 600.85 & 597.02 \\
\hline $\mathrm{B}_{1}$ & 15.79 & 16.14 & 16.51 & 16.45 & 339.10 & 360.37 & 379.21 & 372.40 \\
\hline $\mathrm{B}_{2}$ & 12.88 & 13.21 & 13.65 & 13.55 & 351.54 & 386.37 & 406.64 & 398.29 \\
\hline $\mathrm{B}_{3}$ & 17.90 & 18.45 & 18.73 & 18.59 & 641.58 & 681.14 & 739.85 & 723.68 \\
\hline $\mathrm{B}_{4}$ & 15.80 & 15.98 & 16.41 & 16.22 & 683.08 & 698.09 & 746.37 & 738.02 \\
\hline
\end{tabular}

Legend: $\mathrm{D}$ - dry relaxation, $\mathrm{W}$ - wet relaxation, $\mathrm{F}$ - full relaxation, $\mathrm{C}$ - conditioned sample.

Table 4

\begin{tabular}{|c|c|c|c|c|c|c|c|c|c|}
\hline \multicolumn{2}{|c|}{ Sample } & $A_{1}$ & $\mathrm{~A}_{2}$ & $A_{3}$ & $\mathrm{~A}_{4}$ & $\mathrm{~B}_{1}$ & $\mathrm{~B}_{2}$ & $\mathrm{~B}_{3}$ & $\mathrm{~B}_{4}$ \\
\hline \multirow{5}{*}{ 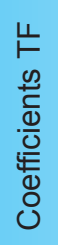 } & & 3.0925 & 88 & 89.2732 & 78.4 & 80.9362 & 66.7810 & 81.0 & 80.5603 \\
\hline & $a_{1}$ & -557.9346 & -435.0830 & -655.7698 & -582.9026 & -600.1090 & -487.4101 & -696.0883 & -614.4097 \\
\hline & $a_{2}$ & 110 & 150 & 02 & 202 & 22 & 73 & 72 & 497 \\
\hline & $a_{3}$ & -3558.7856 & -2586.8595 & -4431.9287 & -4027.6379 & -4116.1078 & -3246.0707 & -4994.1072 & -4475.1907 \\
\hline & $a_{4}$ & 2542.0085 & 1784.0234 & 3258.8111 & 2994.5252 & 3048.9752 & 2369.3912 & 3783.3881 & 3416.4758 \\
\hline
\end{tabular}

Table 3 shows that the value of the TF decreases from full, through a wet to dry relaxation. Knitwear made of $96 \%$ CO and $4 \%$ LY mixture faster returns to its original state due to Lycra effect compared to knitwear made from $100 \%$ cotton. This contributes to the rapid establishment of a stable condition in these knitwear. It is also reducing the length of the yarn loops is more evident in knitted fabric containing Lycra which gives a higher values of TF. Table 4 also shows that thicker knitwear provides greater value of TF comparing with knitwear made of thinner yarn. Also, colored knitwear have higher TF, because during coloring process kneatwear was exposed to temperature tratment and wet processing.

\section{Mathematical model for describing relation}

between TF and value of the yarn's length $\left(I_{0}\right)$ in knitwear's loop

To determine TF dependencies from yarn's length in the knitwear's loop, specific mathetmatical model is introduced. In order to represent method of nonlinear regression, polynomial model is used. For a given set of data pairs $\left(x_{1}, y_{1}\right),\left(x_{2}, y_{2}\right), \mathrm{K},\left(x_{n}, y_{n}\right)$, the following relation should be found, $y=a_{0}+a_{1} x+K+a_{m} x^{m}$, whereby $m \leq n-2$, so experimental data can be the best represented.

The results of experimental research have been approximated by a non-linear model fitting data which has a form of polynomial of degree 4 :

$$
T F=a_{0}+a_{1} l+a_{2} I^{2}+a_{3} I^{3}+a_{4} I^{4}
$$

wherein $a_{0}, a_{1}, a_{2}, a_{3}, a_{4}$ are constants, $I_{0}$ independant variable i.e. length of yarn in the loop twists. As
$I_{0}$ changes in knitwear depending on relaxation, that's TF value changes according to the previous formula. Table 4 gives an overview of the calculated coefficients of the empirical formula for the TF value changes depending on the length of yarn in the loop.

\section{CONCLUSIONS}

This paper analyzes the impact of raw material composition of knitwear, finishing method and fineness of used yarn on dimensional stability of the $1 \times 1$ ribbed knitwear made on the same circular knitting machines. The results obtained show that the most stable are dyed knitwear made of CO $96 \%$ and $4 \%$ of LY and yarn fineness 19.14 tex. According to the results, the knitted fabric with the highest degree of dimensional instability are raw knitted fabric of $100 \%$ $\mathrm{CO}$, yarn made of fineness 13.39 tex.

It can be concluded that values $K c$ and $K w$ increase at knitwear which have LY in their structure, as well as at those which are dyed and those which are made of thinner yarn. $K r$ decreases with an increase of relaxation which means that the loop reaches its stable state and it has minimal ability to change shape. Ks factor raises significantly with the increase of relaxation and with increase of the TF.

It can be concluded that knitwears which show the most stable condition are dyed knitwears made of CO and LY and of thicker yarns. Knitwears with the highest degree of dimensional instability are made of raw knitted fabric of $100 \% \mathrm{CO}$, and of thinner yarn. In complete relaxation, all samples have recorded the largest dimensional change. 
[1] Antônio Augusto Ulson de Souza, Luiz Felipe Cabral Cherem and Selene M. A. Guelli U. Souza, Prediction of dimensional changes in circular knitted CO fabrics, In: Textile Research Journal, Vol. 80(3), pp. 236-252, (2011)

[2] Chathura N. Herath and Bok Choon Kang, Dimensional stability of core spun CO/spandex single jersey fabrics under relaxation, In: Textile Research Journal, Vol. 78(3), pp. 209-216, (2008)

[3] Munden, D. L., The geometry and dimensional properties of single jersey-knit fabrics, In: Textile Research Journal, Vol. 50, pp. T448-T471 (1959)

[4] Petrovic, V. Tehnologija pletenja, Tehnicki fakultet "Mihajlo Pupin”, Zrenjanin, Serbia (2000)

[5] Gersak, J. Objektivno vrednovanje plošnih tekstilija i odjeće, Faculty of Textile Technology, Zagreb (2014)

[6] Bayazit Marmarali, A. Dimensional and physical properties of CO/spandex single jersey fabrics, In: Textile Research Journal, Vol. 73, pp. 11-14, (2003)

[7] Anand, S.C., Brown, K.S.M., Higgins, L.G., Holmes, D.A., Hall M.E. and Conrad, D. Effect of laundering on the dimensional stability and distortion of knitted fabric, In: AUTEX Research Journal, Vol. 2, No. 2, pp. 85-100 (2002)

[8] Knopten, J.J.F., Ahrens, F.J., Ingenthron, W.W. and Fong, W. The dimensional properties of knitted wool fabrics, Part 1: The single jersey structure, In: Textile Research Journal, Vol. 38, pp. 999-1012 (1986)

[9] Mukherjee, Sandip, Ray, Sadhan Chandra, Punj, S.K. Dimensional parameters of $1 \times 1$ rib fabric produced on a circular bed double jersey knitting machine using ultrasonic technique, In: Indian Journal of Fibre\&Textile Research, Vol. 39, pp. 230-237, (2014)

[10] Prakash, C., Thangamani, K. Establishing the effect of a loop lenght on dimensional stability of single jersey knitted fabric made from CO/LY core spun yarn, In: Indian Journal of Science and Technology, Vol. 3, No. 3, pp. 287-289, (2010)

[11] Stojiljkovic, D.T., Petrovic, V., Stojiljkovic, S.T., Ujevic, D. Defining of memory function for tension and deformation of linear textile products on the basis of their rheological models, In: Industria Textila, No. 6, 2009; ISSN $1222-5347$.

[12] Stepanovic, J., Milutinovic, Z., Petrovic, V., Pavlovic, M. Influence of relative density on deformation characteristics of fabrics in plain weave, In: Indian Journal of Fibre and Textile Research, No. 1 Vol. 34, 2009. 69-75; ISSN 09710426.

[13] Radivojevic, D., Stepanovic, J., Stamenkovic, M., Petrovic, V. Analysis of deformation characteristics of twisted woolen yarns, In: Tekstil, No. 11, 2008, pp. 563-568; ISSN 0492-5882.

[14] Stojiljkovic, D.T., Petrovic, V., Dj-Petrovic, M. Rheological modelling of yarn extension, In: Tekstil, No. 9, 2007, pp. 554-561; ISSN 0492-5882.

[15] Salopek, I., Skenderi, Y., Gersak, J. Investigation of knitted fabric dimensional characteristics, In: Tekstil, Vol. 56, No.7, 2007, pp. 391-406; ISSN 0492-5882.

[16] Fatkic, E., Gersak, J., Ujevic, D. Influence of knitting parameters on the mechanical properties of plain jersey weft knitted fabrics, In: Fibres Text. East. Europ., vol. 19, no. 5 (88), 2011, pp. 87-91.

\section{Authors:}

\section{MARIJA PEŠIĆ ${ }^{1}$ \\ VASILIJE PETROVIĆ ${ }^{1}$ \\ JOVAN STEPANOVIĆ ${ }^{2}$ \\ CARIŠA BEŠIĆ ${ }^{3}$}

\footnotetext{
${ }^{1}$ Technical Faculty "Mihajlo Pupin”, University of Novi Sad, Djure Djakovica nn, 23000 Zrenjanin, Serbia

${ }^{2}$ Faculty of Technology, University of Nis, Bulevar Oslobođenja 124, 16000 Leskovac, Serbia

${ }^{3}$ Faculty of Technical Sciences, University of Kragujevac, Svetog Save 65, 32000 Čačak, Serbia

e-mail: marija.stankovic.986@gmail.com; vlp@eunet.rs; jovan@tf.ni.ac.rs; carisa.besic@ftn.kg.ac.rs
}

\section{Corresponding author:}

\section{MARIJA PEŠIĆ}

e-mail: marija.stankovic.986@gmail.com 